\title{
THE COURTAULD COLLECTION AS A TEACHING TOOL
}

\section{J.A. Maritz, University of Zimbabwe}

Although western civilization has its roots in Classical antiquity, much of the Greek and Roman world is strange to us. This is particularly true in Southern Africa where we do not have the Romance languages, nor the physical remains - roads, bridges, aqueducts, villas, often still in the process of being excavated - surrounding us and therefore do not experience the same continuity of history as our European or British colleagues. It is also difficult to visualize the material culture. Photos help, but do not convey a sense of scale, or texture. Real understanding often depends on a hands-on experience, or at least a look at the original.

Here again teachers in Southern Africa are at a disadvantage, being far from the largest museums. There are however various collections which, although small, contain fine specimens of classical artefacts which can, and should, be used as teaching tools to make our subject more concrete and intelligible.

One such collection is the Courtauld collection of Greek and Roman coins of the University of Zimbabwe. The aim of this paper is to introduce the collection to a wider audience and give some indication as to how it is being used as a teaching tool.

Stephen Lewis Courtauld, grandson of the founder of the Courtauld textile empire, emigrated to the then Rhodesia in 1950 and was knighted for his cultural and philanthropic work there, in 1958. At his death on 9 October 1967, at the age of 84, his estate was estimated at some $£ 30$ million. One of his many interests, made possible by an income of this size, was numismatics. Between 1920 and 1955 he built up a collection of some 116 Greek and 148 Roman and related coins. This was not a random or haphazard collection, but one carefully selected to represent the main types of currency in the Greek world of 5 th and 4th centuries $\mathrm{BC}$, the empires of Alexander and his successors as well as "the whole great sweep of some eight centuries of Roman coinage" (R.A.G. Carson in his introduction to Carney 1963), its changing monetary systems and denominations, the development and deterioration of aesthetic standards, the political, military and economic history of Rome.1

Not only did Courtauld choose each coin for its contribution to the whole collection, but also for its own intrinsic value. All coins are in a superb condition; many are works of art in their own right, and several are also exceedingly rare - the Syracusean silver dekadrachms of Kimon and Euaenetus (P35, P37, P38); the electrum stater of Miletus of which only 6 other specimens are known (P97); a silver tetradrachm of Amphipolis in a die combination of which only one other specimen, now in the Hunterian museum in Glascow, is known (P47).

Sir Stephen contributed to the founding of the University College of Rhodesia and Nyasaland, and presented his collection as a foundation gift, with the request that it be published, and be used as a teaching tool. The first catalogue, $A$ Catalogue of the Roman and Related Foreign Coins in the Collection of Sir Stephen Courtauld2 by T.F. Carney, first Professotr of Classics at the new University, was published in 1963. The second, Greek Coins in the Courtauld

1 Incidentally, the University is singularly fortunate in having also the Pallett collection of coins, so that it also has a selection of Mediaeval coins, and coins of all except two English monarchs up to Elizabeth II.

2 This will be referred to as C, and the catalogue of Greek coins as P; e.g. P97 is coin number 97 in Pollard's catalogue. The Camey catalogue is now out of print; the Pollard catalogue is available from the Publications Office, University of Zimbabwe, P.O. Box MP 167, Harare, Zimbabwe. 
Collection by J.G. Pollard, Keeper of Coins and Medals at the Fitzwilliam Museum, Cambridge, appeared in 1970. In his introduction Pollard writes: "l have followed Carney's lead and borne in mind the situation of the student in the Universities of the African continent where access is limited to comparative materials (sic) and to the full range of publications. The text attempts notes to the coins to indicate their historical position and the particularity of their types. The bibliographical references contain the standard and latest references in a manner to facilitate inquiry to libraries outside Africa ..." The review announcement appeared in Akroterion XVII (March 1972).

Sir Stephen's wish that the collection be used as a teaching tool has been fulfilled; during the 60 's the coins were not only used at the University but taken to schools and passed around the class. At that stage the collection was housed in the library; later security became an issue, and it was moved to the vaults of the Reserve Bank. It is brought to the University at the request of the Librarian, usually once a year. The coins are displayed in their perspex boxes, both faces visible but untouchable. Luckily there are also a dozen very worn coins not belonging to the collection, a gift of Michael Metcalf of the Ashmolean, that can be handled and these are used in lectures to give students the "feel" of ancient coins.

On Open Days large black and white photos of a few coins are displayed, but the usual manner of presentation is through the slides, obverse and reverse of each coin. These are used to illustrate various courses, and although a short article cannot cover all the coins, I hope it may give an indication of the range of the collection and its applications.

\section{NUMISMATICS}

Numismatics is one of four topics covered in alternate years as part of the History, Art and Archaeology paper for Classical Studies II and III (CLS 202, 302). It comprises 12 lectures which cover the origin of coinage, minting techniques, weights and standards, terminology, types, coins as a form of art and as a means of communication and propaganda.

P97, the rare electrum stater of Miletus c.575 clearly shows how coinage originated, using probably the insignia of the ruler (the issuing authority) as the type. These early coins were thick, not regular in shape, and struck.

Electrum occurred naturally in Lydia, and was used for the earliest coins. As the proportions of gold and silver were not constant, it was soon replaced by these metals in pure form, struck to specific standards. There are examples of the Euboaean standard, Corinthian standard, Athenian standard, etc. In Italy copper was the locally available metal and early Roman coinage utilized it. The collection also has specimens of the major Roman issues in silver and gold as well as in orichalchum, the yellow brass that Julius Caesar introduced to resemble gold.

The manufacture (literally, as the process was done by hand) of coins involved placing a round flan of metal, of a pre-determined weight, on a die set into an anvil, and striking it with a hammer/mallet into which another die had been inserted. The force of the blow caused the metal to bend slightly, forming a convex face on the side which was on the anvil (the obverse i.e. "heads") and a concave face on the side struck by the mallet (the reverse, i.e. "tails"). Many of the coins show the convex/concave difference clearly. The mark of the issuing authority, for example the turtle of Aegina, Pegasus for Corinth, the owl of Athens, and in the Hellenistic and Roman periods the portrait of the ruler, appears on the obverse; this gave rise to the term "heads" - a misnomer, as there are examples in the collection where there is a head on the reverse, for example P15, a silver tetradrachm from Rhegium, which has a lion's scalp on the obverse and the head of Apollo on the reverse. 
Sometimes there is a head on both sides. In these cases that on the obverse is considered the most important, so for example Antony, the senior partner, appears on the obverse and Octavian on the reverse of the denarii issued in $41 \mathrm{BC}$ (C45 and 46). Agrippina's dominance over Claudius is implicit in her monopolizing the obverse face of a sestertius of 52-54 AD (C76).

Most dies had a design engraved or sunk into them so that the resulting coin has its type in relief, but in Magna Graecia there was a tendency to have the type in relief on the obverse, and the same design set in a frame, often a cable design, in incuse on the reverse. One theory is that this was the result of Pythagorean influence (which was strong in the area) which linked pairs of opposites. The collection includes several coins which have the type in relief on the obverse and incuse on the reverse, for example P5, a silver stater of Metapontum showing an ear of barley. Others show the type reversed and incuse, for example on P9, a silver stater of Syrbaris of c.560 BC, the bull faces right on the obverse but left on the reverse. An interesting variant is P8, a silver stater from Poseidonia, which on the obverse shows Poseidon, his chlamys looped over his arm away from the viewer, and on the reverse he is shown with it draped across his body.

Other methods of manufacture are also illustrated in the collection. P46 from Neapolis, Macedonia, c. $480-460 \mathrm{BC}$ shows on the reverse that the "die" was 4 metal bars tied together. Occasionally coins were cast, not struck. P82, a silver stater from Elis c.380 BC, shows the protrusions which originally joined the coin to the next one in the mould.

There are also examples of a flan slipping during the striking process, resulting in the type being off-centre. The obverse of P23, a silver tetradrachm from Himera c. $440 \mathrm{BC}$, shows that there were rust marks on the die and P45, a silver tetradrachm of Mende c. 445 BC with a type of Dionysus, shows die flaws in the field.

A strong, stable currency kept its type basically unchanged (and so recognizable and accepted) over a long period, e.g. the "owls" of Athens and the "foals" (Pegasus) of Corinth. The Courtauld has two examples of each, from different centuries (P74, 75, 77, 78). Types may refer to a local deity (Athena in Athens), a product (barley for Metapontum P5-7, grapes for Naxos P26, cattle on Euboea P71-2), a well-known feature (the labyrinth of Knossos P86) or be a pun on a name (a rose for Rhodes P101). They may indicate political alliances (the shield of the Boeotian League P70). Often the type alone was sufficient identification, but sometimes a legend (i.e. writing in the field) was added (META for Metapontum or POS for Poseidonia, sometimes written retrograde as on P8).

When the young Roman Republic started issuing coins, it copied those of its neighbours and used types similar to those of the regions in which she wanted her coinage accepted, e.g. C1, a silver didrachm of 269-242 BC, is similar to the bronze coins of Cosa in Etruria after 273 $\mathrm{BC}$, and $\mathrm{C} 2$, another silver didrachm of the same date, shows the wolf suckling the twins. The bust of Heracles on the obverse is also found on the coins of Capua which had a doe suckling Telephus on the reverse. To indicate its origin the Romans added a legend, ROMANO or ROMA. The Romans made more use of legends than the Greeks had done, often adding the value of the coin ( $C 9$ shows a $V$ for 5 asses on a quinarius), the mint mark (e.g. $\mathrm{C} 8)$ or the name of the moneyer $(\mathrm{C} 19$, a silver denarius c.145-138 BC with NAT for NATTA, the moneyer, on the reverse).

The re-organization and stabilization of the Roman coinage during the Republic introduced typically Roman types like Roma, the Dioscuri, a prow, Mars. Aristocratic republicans commemorated the achievements of their ancestors, like Q. Capio Brutus who used the heads of L. Junius Brutus and C. Servilius Ahala on a silver denarius of c.60 BC. Julius Caesar is credited with introducing contemporary portraiture (his own likeness in the guise of Pietas on C39), and this became standard practice. 
Under the emperors the legend often includes all the ruler's titles, or the plain SC (Senatus Consultu) if issued by the senate. The varying fiscal policies and economic reforms of each emperor can also be followed from the coinage - debasement of silver with an alloy of copper; increasing or decreasing the weight of the coins; introduction of new coins like the gold solidus of Constantine which remained acceptable for centuries.

\section{$2 \quad$ ART}

Other topics covered in the History, Art and Archaeology paper (CLS 202/302) are Sculpture and Pictorial Art. The Courtauld coins are used in these courses as comparative material to illustrate relative chronology, types, styles and principles of composition.

Certain types show interesting correspondence between subjects in different media. The Gorgon head on the stater of Neapolis (P46) is reminiscent of that on the temple of Artemis at Corcyra and one in the Acropolis museum in Athens (Richter 1965 figs.76, 180); the bearded Dionysos on the Naxos stater (P26) recalls the Bluebeard pediment on the Acropolis at Athens (Richter 1965 fig.378); Arethusa on the Syracusean tetradrachm of c.450 BC (P34) is similiar to the Lapith woman on the pediments of the Temple of Zeus at Olympia (Richter 1965 fig.392; Ashmole-Yalouris 1967 fig. 114); the striding Apollo on the stater of Caulonia (P12) recalls many statuettes of throwing and striding figures of Zeus, Poseidon and Herakles (Richter 1965 figs.99-102); animals and chariots have their equivalents in other media. ${ }^{3}$ These may all be used to illustrate comparative dating and relative chronology.

Some characteristic lines of development in Greek art are well illustrated on the coins, e.g. changes in depicting the profile eye, from a frontal eye set on a profile face to one in true profile. The archaic type appears on the obverse of $P 74$, a silver tetradrachm from Athens c. $500-480 \mathrm{BC}$, the classical type on P75, a similar coin of $443-440 \mathrm{BC}$, and a true profile on P79, a silver stater from Corinth c. $310-300$ BC. 4

Another important innovation was the depiction of a frontal or three-quarter face. Kimon used a three-quarter view for the head of Arethusa on a Syracusan silver tetradrachm of 412-411 BC (P35). Copies of this coin appear at Catana (P20), at Croton (P14), at Amphipolis (P47), and Larissa, Thessaly (P67). In vase painting this appears on white ground lekythoi of Group $R$ at the end of the 5th century BC, and in the work of the Niobid Painter, the Meidias Painter and the Marsyas Painter (Arias-Hirmer 1962 figs.173-179, 200, XLV, 215, XLVI, XLVII).

Increased knowledge of human anatomy, and the use of foreshortening is usually illustrated from vase painting or relief. It can also be seen on the coins. P27, a silver tetrachm from Naxos c. 460 BC shows on the reverse a naked, squatting Silenus holding a kantharos where the depiction of the inside of the leg and a frontal foot recalls the Achilles of the Sosias painter (Arias-Hirmer 1962 fig.118).

Ways of portraying depth and movement can be traced in the depiction of the quadriga on Syracuse coins, e.g. P37 by Kimon, c.405 BC, and P38 by Euaenetus, c.395 BC.

3 A comparison of the depiction of horses, bigas and quadrigas on vases from the Geometric period onward, sculpture (e.g. on the Sikyonian treasury at Delphi and the Parthenon frieze) and coins is particularly interesting. See $P 19,20,21,23,25,29,33,34,35,37,38,42$ and Arias-Hirmer 1962 figs. 5, 10, XI, 37, 40-44, 49, 81. This can be continued into the Roman period, e.g. the chariot on the Arch of Titus and of Marcus Aurelius. For illustrations see Strong 1976 fig.69 and Ryberg 1967 fig.13. For other animals see Richter 1965 figs.340f. and compare e.g. the goat of fig. 362 with P57 and the lions with P96 and 97.

4 For comparative material see Arias-Hirmer 1962, e.g. figs.XII, 92, XXXIX. 
Composition, encompassing a design satisfactorily within a set field, is a major aspect of Greek art. The circular shape of the flan provided a challenge that could be met in different ways - a single figure or a group; set free in the field, within a border, or set on a chord to form an exergue beneath. Examples of all these are found in the Courtauld collection.

Splendid examples of designs tailored to the round field are P18 showing two eagles, one with its head thrown back and the other bent forward, on a silver tetradrachm of Acragas c.420$415 \mathrm{BC}$, or P71 which has a cow with head turned back to lick her raised hind leg, on a silver didrachm of Eretria, Euboea, c.525-515 BC, a device similar to that used on the metope of Herakles and the Cretan bull at Olympia (Richter 1965 fig.355).

Again there are interesting parallels with pottery, specifically the tondo within cups - a head within a border on a Late Corinthian cup c.560 BC (Arias-Hirmer 1962 fig.34); the feet of an archer following the circumference of the field on a plate by Epictetus c.520-510 BC (AriasHirmer 1962 fig.98); a chord drawn across the Laconian cup by the Arcesilas painter to divide the scene of the king weighing wool (silphium?) from that of the slaves stacking it away (Arias-Hirmer 1962 XXIV). A similar link between the subject matter of the two fields is found on the Syracusan tetradrachm P38 where the main field shows a chariot race and the exergue the prizes.

Roman coins often show a more crowded composition. A coin of Nero (C79) shows the harbour of Ostia complete with a breakwater, 7 ships, a lighthouse topped by a statue of Neptune, and a reclining figure of the Tiber. This is shown in bird's eye perspective similar to that used in the fresco from Stabii showing a harbour scene (Wheeler 1964 fig.185), or the one from Pompeii showing the inside as well as the outside of the amphitheatre furing the riot of $59 \mathrm{AD}$ (Wheeler 1964 fig.96, Woodford 1982 fig.83).

Historical relief, i.e. scenes which refer to actual events, is common in Roman art, e.g. on the Ara Pacis, Arch of Titus or Trajan's Column. The allocutio scene on the panel reliefs of Marcus Aurelius (Ryberg 1967 fig.37a, b) is paralleled by that on C113 of the Emperor (in this case Commodus) haranguing his troops and $\mathrm{ClO2}$ shows Hadrian with the personification of Africa, commemorating his visit to the province.

Like vase painters, die engravers sometimes signed and labelled their work. Artists' signatures represented in the collection, are those of Kimon (P35), Euaenetus (P21 and 38), Olym(pias?) (P84) and Heracleidas (P20), and the prizes on P38 are labelled.

\section{HISTORY}

Ancient History is not taught as a separate subject at the University of Zimbabwe, but as part of the Classical Studies courses CLS 102, 202 and 302. Coins are of course a primary source for history, as is ably demonstrated in two useful books (Grant 1958, Sutherland 1987). The Courtauld coins can be used as evidence for alliances, trade patterns and economic tendencies, 5 but even small points can be illustrated from the collection, e.g. P75 shows Athena wearing a laurel wreath, presumably added to the previous type after the victory over the Persians.

Portraits are of inestimable value in teaching history, and the collection includes many, e.g. Alexander the Great on a silver tetradrachm of Lysimachus minted in Magnesia c.297-282 (P62), Seleucus on a silver tetradrachm minted in Persepolis c.312-280 (P102), Eucratides of

5 The catalogues of Pollard and Carney give useful notes on these points. A good example is that of Eretria in Euboea, P97 and 72, where a change to the Aeginetan standard, conforming to Peloponnesian practice, mirrors the revolt from Athens in 411 . 
Bactria on a silver tetradrachm of c.170-150 (P109) and Antony and Cleopatra on a silver tetradrachm minted in Antioch c.36-30 BC (C53).

All the Roman emperors are represented, even those who ruled only briefly, and often also their families. One of the most interesting is C91, a denarius of Domitian which shows his infant son (by Domitia, Corbulo's daughter) seated on a globe.

\section{COMMUNICATION/PROPAGANDA}

In an age when there was no radio, no TV, no films and no daily newspapers, coins provided a means of disseminating information across the empire. One of the best known examples is a denarius of Brutus issued in 43-42 BC which has on the reverse the cap of Liberty between two daggers, with EID MART (the Ides of March) below. Ironically the man who objected to Caesar acting as a king had his own portrait on the obverse (C41).

Under the Roman Empire news of important events was publicized on the reverse of coins, e.g. the as showing a crocodile (the symbol for Egypt) in collar and chain, issued by Octavian after the battle of Actium (C54). Nero's re-building of the harbour at Ostia (C79), and Trajan's campaigns and the bridge over the Danube (C96) provide other examples.

News can of course be slanted, and portraits could be presented to convey a specific "image" by association, e.g. on $\mathrm{C} 68$, an orichalchum sestertius of c.37-51, Caligula shows his sisters Agrippina, Drusilla and Julia as Securitas, Concordia, Fortuna; this was meant to show the solidarity of the imperial house and associate them with peace and prosperity. A bronze of Nero showing the temple of Janus with its door closed, issued c.64-65 AD (C78) was probably also meant to counteract his growing unpopularity by associating him with peace and the memory of Augustus.

\section{BUILDINGS}

Architecture is taught as a topic in alternate years in the History, Art and Archaeology paper CLS 202/302. Although coins are not the most important source for this, many buildings are known to us through representations on coins, and many details, e.g. of roofs and entablature, can be reconstructed from these. Examples found in the Courtauld collection are an octostyle temple on a silver coin of Juba I c.60-46 BC (C37), the temple of Janus mentioned above (C78) and the Circus Maximus on an orichalchum sestertius of Trajan c.103-111 AD (C97). The harbour at Ostia (C79) and Trajan's bridge (C96) are other architectural features appearing on coins.

\section{RELIGION}

Many, indeed most, of the main Graeco-Roman gods appear on coins, with their attributes. Under the Empire there are also many personifications of abstract deities such as Spes, Concordia, Securitas and Pax, and the personfications of the provinces. There are also representations of religious objects, e.g. the sacrificial implements on the aurum of Caesar 46 BC (C39). Under the Christian emperors the chi-rho sign is used, e.g. on a quarter bronze of Theodosius 383-388 AD (C144) and a solidus of Honorius in $422 \mathrm{AD}$ (C146).

\section{LANGUAGE}

Various linguistic phenomenon can be seen on the coins, e.g. P77, a silver stater from Corinth of c.520 BC shows the Koppa on the obverse. This letter was of course not used in 
classical times. Abbreviations abound (SC, IMP, COS, V, X) and the coins can be used as source material for these. There are also coins with Punic inscriptions, e.g. P43, a SiculoPunic silver stater of c. $370 \mathrm{BC}$ reads MMHNT (people of the camp).

What is the value of this collection? Here I am referring not to its monetary value, which I always (truthfully) say that I do not know, but to its pedagogical value, and I would suggest the following:

1 Coins are concrete, familiar objects, understandable to our students (perhaps this will remain true longer in Zimbabwe than elsewhere where credit cards are replacing them). They provide a real, tangible link with the past, and possibly a touch of the romantic who else has held this before me?

2 We as teachers of Classics are constantly being asked for a rationale for our subject. Martin Price, numismatist at the British Museum, when asked what a numismatics course should offer, replied, "Teach the students to LOOK". The ancients looked at their coins; they were a medium of communication as well as of exchange. We who have so much visual material in the form of books, magazines, films, TV, video, billboards, neon lights, etc. thrown at us continually, are actually very unobservant. Anything that teaches us to look, examine closely and critically, has a real educational value.

3 The collection can be used at a variety of levels. It is available for specialized scholarly research, and fascinates primary school youngsters. In schools where Classics is not taught, "Money" as a topic for projects is, and this offers us an opportunity to teach some classical material within the existing syllabus. Also, A-level students in their General Paper on the use of language deal with information media - coins as a propaganda tool comes as something of a revelation, though the comparison with postage stamps is easily made. Various associations, e.g. Rotary and the International Women's group, have asked to hear about the collection. Money talks - and the Courtauld coins say a good deal to a wide audience.

4 The Courtauld collection itself could be used more widely, e.g. if there were a course in Economic History of the ancient world. I should also be glad to know if any interest exists for us to consider making sets of slides from the collection to illustrate various topics or themes.

5 It may also inspire one to look again at other collections and to use coins in teaching. There are several collections in South Africa, e.g. at the Universities of Stellenbosch and Rhodes, and the Cultural History Museum in Cape Town (see Saddington 1987, Van Stekelenburg 1978). Real Roman coins, in less perfect condition than the Courtauld's but genuine none the less, can be bought for a couple of pounds in Britain, and replicas in sets are available at museums or National Trust sites. One does not have to be a millionaire to own coins, nor a numismatist to use them; they are a valuable teaching tool for any Classicist.

\section{BIBLIOGRAPHY}

Arias, P.E. and Hirmer, M. 1962. A history of Greek vase painting. London: Thames and Hudson.

Ashmole, B. and Yalouris, N. 1967. Olympia; the sculpture of the Temple of Zeus. London: Phaidon Press. 
Carney, T.F. 1963. A catalogue of the Roman and related foreign coins in the collection of Sir Stephen Courtauld. Salisbury (Harare): University College of Rhodesia and Nyasaland.

Crawford, M. 1974. Roman Republican coinage. Cambridge: Cambridge University Press.

Grant, M. 1954. Roman Imperial Money. Nelson; 1958. Roman history from coins. Cambridge: Cambridge University Press.

Kraay, C.M. and Hirmer, M. 1966. Greek coins. London: Thames and Hudson.

Laing, C.R. 1969. Coins and archaeology. London.

Pollard, G. 1970. A catalogue of the Greek coins in the collection of Sir Stephen Courtauld. Salisbury (Harare): University College of Rhodesia and Nyasaland.

Richter, G.M.A. 1965. The sculpture and sculptors of the Greeks. Yale University Press.

Ryberg, I.S. 1967. Panel reliefs of Marcus Aurelius. New York: Archaeological Institute of America.

Saddington, D.B. 1987. Some unpublished Hispano-Roman coins in the Mann Collection in the Cultural History Museum, Cape Town. Akroterion XXXII 3/4, 94-98.

Seltman, C. 1955. Greek coins. London: Methuen.

Strong, D. 1976. Roman art. Penguin.

Sutherland, C.H.V. 1974. Roman coins. London: Barrie \& Jenkins; 1987. Roman history and coinage. Oxford: Clarendon Press.

Van Stekelenburg, A.V. 1978. Coins of the Roman Republic from the collection of the University of Stellenbosch. Akroterion XXIII 3, 9-23.

Wheeler, R.E.M. 1964. Roman art and architecture. London: Thames \& Hudson.

Woodford, S. 1982. The art of Greece and Rome. Cambridge: Cambridge University Press. 


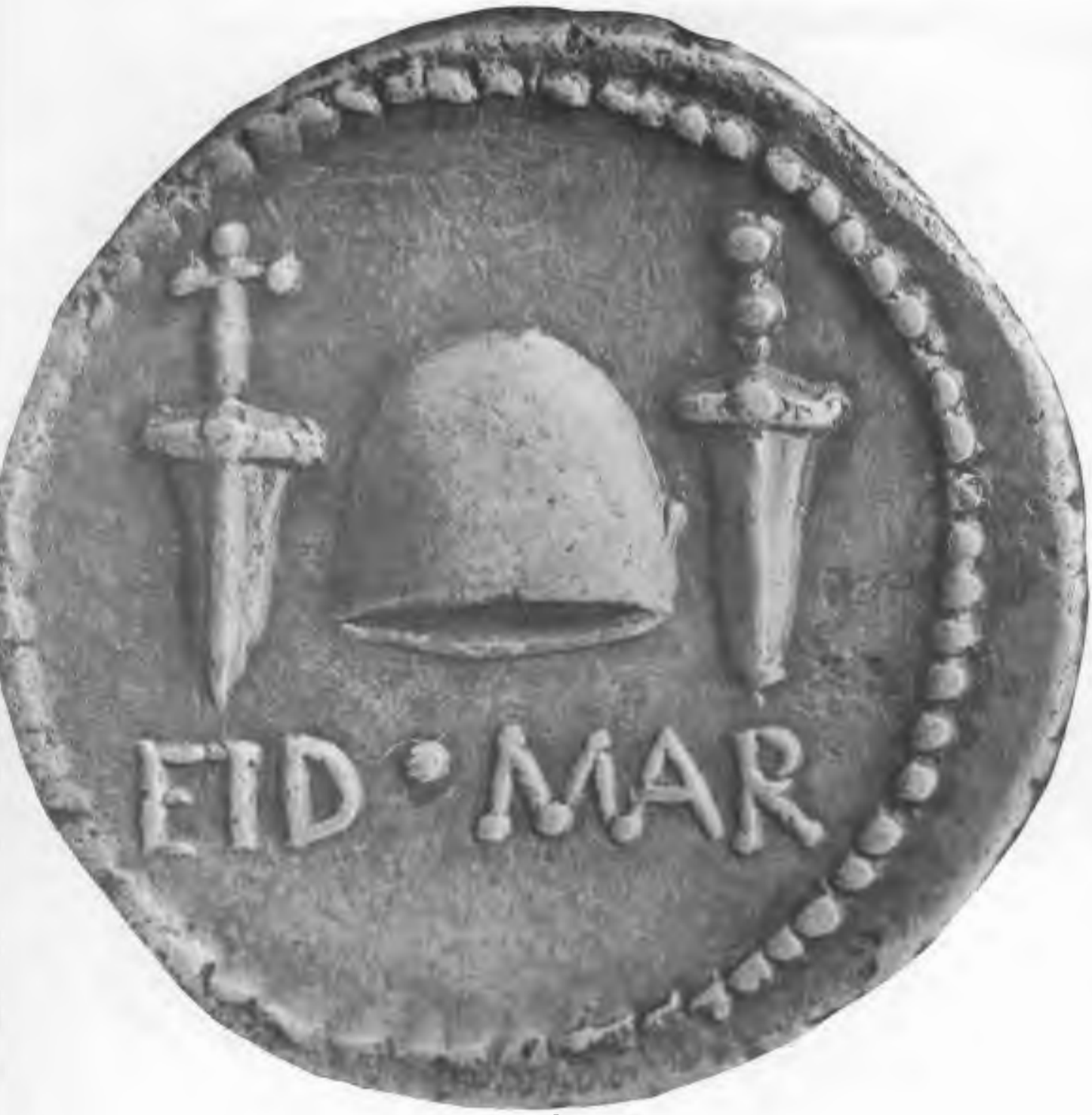

c.41 43-2 BC

Silver Denarius. Struck by M Junius Brutus and L. Praetorius Cestianus to announce the freedom won by Caesar's association

Reverse: Cap of Liberty between 2 daggers; EID MAR 


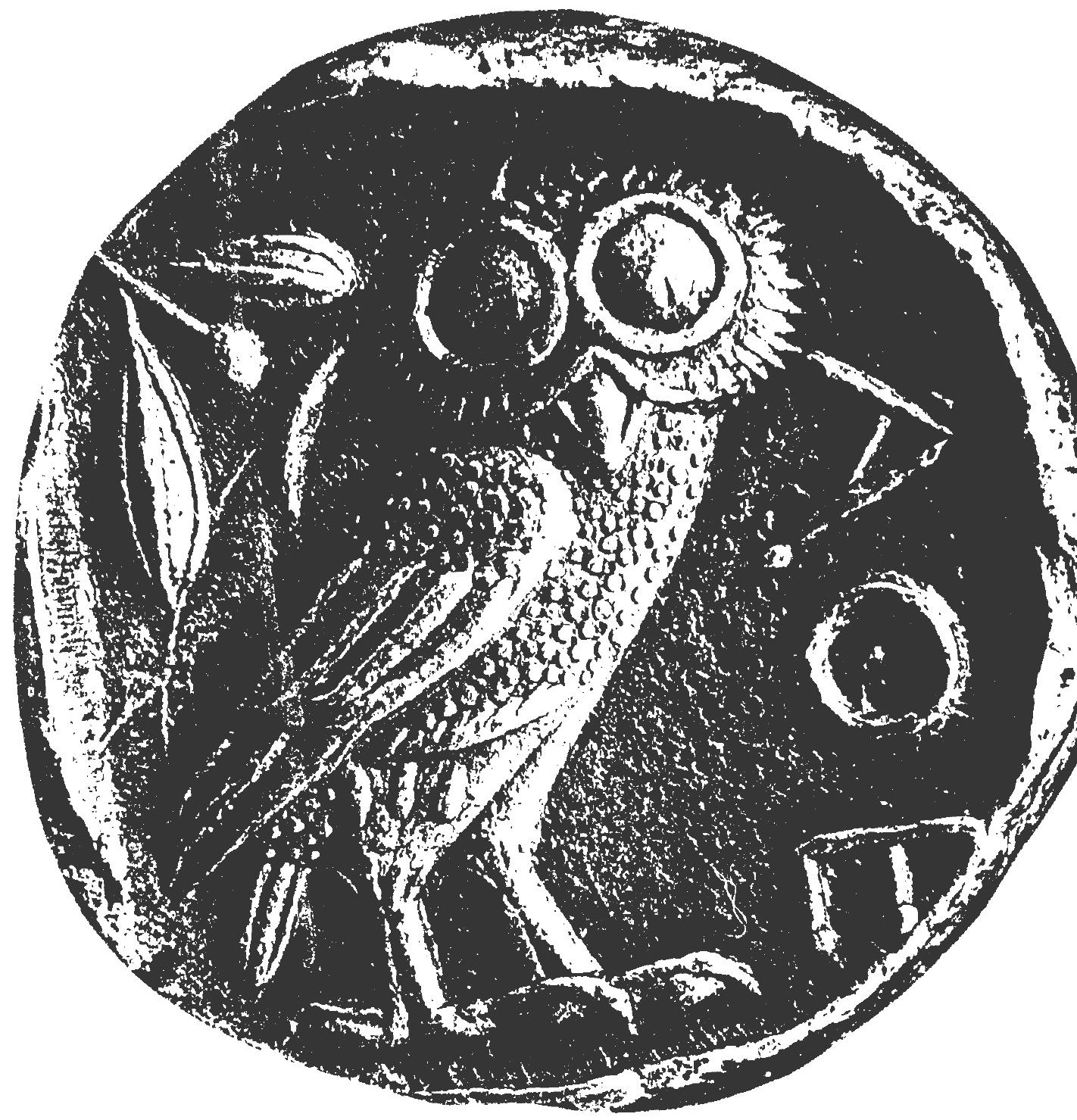

P75 c440-430 BC

Silver tetradrachm of Athens

Reverse: Owl, olive spray and crescent moon.

$\mathrm{A} \theta \mathrm{E}$ in field, all set in square incuse 